\title{
Hard labour and punitive welfare: the unemployed body at work in participatory performance
}

Article

Accepted Version

Bartley, S. (2017) Hard labour and punitive welfare: the unemployed body at work in participatory performance.

Research in Drama Education, 22 (1). pp. 62-75. ISSN 13569783 doi: https://doi.org/10.1080/13569783.2016.1263559 Available at https://centaur.reading.ac.uk/91731/

It is advisable to refer to the publisher's version if you intend to cite from the work. See Guidance on citing.

Published version at: https://www.tandfonline.com/doi/full/10.1080/13569783.2016.1263559

To link to this article DOI: http://dx.doi.org/10.1080/13569783.2016.1263559

Publisher: Taylor \& Francis

All outputs in CentAUR are protected by Intellectual Property Rights law, including copyright law. Copyright and IPR is retained by the creators or other copyright holders. Terms and conditions for use of this material are defined in the End User Agreement.

$\underline{\text { www.reading.ac.uk/centaur }}$

\section{CentAUR}


Central Archive at the University of Reading

Reading's research outputs online 


\title{
Hard Labour and Punitive Welfare: The Unemployed Body at Work in Participatory Performance.
}

\author{
Sarah Bartley, Queen Mary University of London, London UK.
}

\section{s.e.bartley@qmul.ac.uk}

This article addresses the performance of labour in participatory arts projects and considers the implications of such activity on perceptions of the unemployed in the UK. Utilising a combination of biopolitical and necropolitical understandings of governance and drawing on two examples of theatre practice, Tangled Feet's One Million (2013) and Helix Arts MindFULL (2013), I propose that participatory performance deploys bodily strategies to disrupt the construction of the unemployed in political rhetoric. As such, in a context of austerity, I argue this arts practice can function to support the agency of participants in challenging policy and seeking to re-establish the status of subjecthood to their precarious bodies. Additionally, I posit that specificities of the unemployed as a participant group illuminate broader complexities around value exchange within participatory arts practice.

Keywords: Unemployment, embodiment, social policy, applied theatre, participatory arts

Sarah is a PhD researcher, her project explores artistic representations of the welfare state, with a particular focus on participatory practices engaging unemployed people. She is an editorial assistant at Contemporary Theatre Review and also works as a drama facilitator.
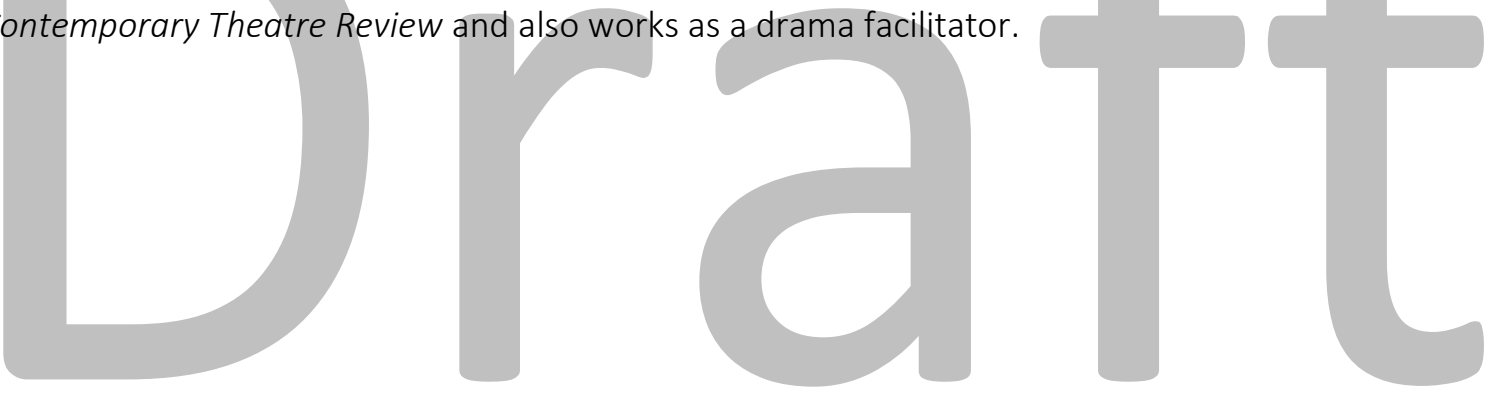


\section{Hard Labour and Punitive Welfare: The Unemployed Body at Work in Participatory Performance}

'[I]t is crystal clear to me that the body is an accumulation strategy in the deepest sense'

(Donna Haraway 1995, 510).

Following the global economic crash of 2008, welfare legislation in the United Kingdom (UK) became increasingly intertwined with, and oppressively enacted upon, bodies. In a context shaped by an economic policy of austerity, the unemployed body in particular, has become a contested site on which relationships between state power, neoliberal values, and individual responsibility are played out. ${ }^{1}$ As of April 2016 there were 1.67 million people unemployed in the UK (ONS 2016). In the six years since the election of a Conservative-Liberal coalition government in 2010, and the subsequent election of a Conservative majority government in 2015 , the UK benefit system has been subject to its most significant reform since the National Insurance Act was passed in 1946 . The social security measures (including financial support for the unemployed and those living in poverty) introduced by the 1946 act have been eroded by the Welfare Reform Acts of 2012 and 2016. During this period access to state welfare has become increasingly contested. Since 2010 the number of financial sanctions applied to claimants due to a perceived failure to comply with the conditions of their benefits has doubled. ${ }^{2}$ This has left claimants in a position of acute precarity, with a $700 \%$ increase in the use of food banks between 2010-2015 constituting a worryingly indicative statistic (Trussell Trust, 2015).

Concurrently, there have been a number of important applied theatre and participatory arts projects addressing unemployment and directly engaging unemployed people as actors and creators. In this article, I examine how unemployed identities are constructed in the current welfare context and unpack the politics of arts practices that stage unemployed individuals hard at work. My aim is to understand the significance of artistic production that engages a group explicitly identified as unproductive. I consider the positive potential of reanimating these unemployed individuals as productive in performance, whilst also acknowledging the problematic implications of such arts 
practice as a means to perform productivity. Drawing on two projects -Tangled Feet's One Million (2013) and Helix Art's MindFULL (2013) - I argue that the bodily practice of participatory performance usefully challenges the construction of the unemployed body in political rhetoric. Further, I propose that specificities of the unemployed as a participant group provoke concerns around the valorisation of labour in participatory performance and illuminate the complexities of value exchange within such arts practice.

In State and media discourse unemployed citizens are subject to constant corporeal misrepresentations of the unemployed body in states of action or inaction, as well as corporeal miscategorisations that classify the body in terms of fitness or unfitness in relation to what the State recognises as an ability to work. Given these two inflections, throughout this article I draw on the terms 'body' or 'bodies' to refer to unemployed subjects. While I am aware that this could be read as contributing to the dehumanisation of these individuals, in reappropriating the terms I intend to demonstrate how those individuals can strategically deploy their own bodies in performance as a tool to regain subjecthood. Given the political landscape this article attends to, alongside my particular focus on bodies, lives, and the governance of corporeality, the concepts of biopolitics and necropolitics provide a useful framework for my analysis. Michel Foucault describes biopower as that which 'would no longer be dealing simply with the legal subjects over whom the ultimate domination was death, but with living beings, and the mastery it would be able to exercise over them would have to be applied at the level of life itself' $(1978,142-3)$. Biopolitics offers a useful critical lens through which to consider the life governing systems embedded within welfare policy and the bodily practice involved in the performances I examine. Additionally, as precarity and mortality increasingly pervade the UK benefit system, this biopolitical focus is combined with a necropolitical analysis, wherein as political scientist Achille Mbembe proposes '[t]o exercise sovereignty is to exercise control over mortality and to define life as the deployment and manifestation of power' $(2003,12)$. A consideration of necropolitics thus allows for an exploration of the systems of power involved in the increasingly threatened corporality of unemployed individuals. 
These two concepts work in tandem to critique the UK welfare system and concurrently reveal the potential resistances and political ambiguities of the performances I examine.

Tangled Feet's One Million was a free, large-scale outdoor performance spectacle which fused drama, live music, poetry, dance, and acrobatics. It was performed at London's Greenwich and Docklands International Festival by 80 young people who were unemployed at the time of the performance and 10 professional performers. ${ }^{3}$ Focusing on youth unemployment in the UK, the production took place on scaffolds creating one central tower and two giant moving staircases, which traversed through the audience. An extensive lighting rig was complemented by torches, glosticks, luminescent costuming, and fireworks, all contributing to the creation of a carnivalesque atmosphere. Performers frenetically clambered around the set enacting choreographed vignettes depicting fierce competition for vacancies, bin bound CVs, and stressful interviews. The performance contained no dialogue; scenes were entirely gestural. Poet Anthony Anaxagorou's lone voice, laced with something of the shamanic, stood in contrast with this mass of performing bodies. His stirring words, set to an original electro-orchestral score composed by Guy Connelly and Nick Gill, narrated disparate journeys through the job market. This live music oscillated between monotonous synth and rousing vocal harmonies. The piece concluded with fireworks exploding over a roaring crowd, a moment of jubilation, a message of intent.

MindFULL, a collaboration between Helix Arts and mental health organisation Tyneside Mind, was undertaken with claimants in receipt of a form of state financial support known as Employment Support Allowance (ESA), given to those unable to work due to illness or disability. During the project, participants shared their experiences of accessing ESA in multi-art form workshops and produced a short film, But I'm Here for Mental Health, outlining their stressful encounters with the Work Capability Assessment (WCA), a State sanctioned process that evaluates people's fitness to work. The film follows three characters (created as a composite of the group's experiences) through the WCA, from filling out the initial claim form to attending an assessment 
centre and, finally, receiving a decision letter. The scenes are short and largely set in the institutional space of the assessment centre depicted with an insipid colour palette, evoking a familiar bureaucratic aesthetic. The interior experiences of the claimant characters are narrated as voiceovers and as such we see their experiences unfold but rarely hear them engage in dialogue. The script was collaboratively written by the participants and Helix Arts and shot with actors in order to preserve the anonymity of participants. The film was released to coincide with the publication of the Litchfield Review, an independent review of WCA, and screened at Northumbria University for an invited audience of Local MPs and employment service providers.

\section{Visibility, Productivity, Participation: Gestural Defiance or Exploitation?} Youth unemployment in the UK exceeded one million in August 2011 and stood at over 950,000 when Tangled Feet's production opened in 2013 (ONS, 2011/2013). Alongside this, unpaid internships and underemployment proliferate, accompanied by a growing demand that claimants 'work for their benefits'. From 2017 the UK government's Earn or Learn Taskforce (headed by MP Matthew Hancock) will remove housing support from those under 21 and introduce a policy of mandatory unpaid community work as soon as young people access benefits. Further, in 2015 , then Chancellor George Osborne announced that 16-24 years olds in employment would not receive the new National Living Wage ( $£ 7.20)$ but remain on the basic Minimum Wage $(£ 6.70)$. Hancock defended the move by claiming young workers were not 'productive' enough to warrant the higher wage (Hancock in Dathon 2015). Returning to Membe's outlining of necropolitics, I propose that this exclusion from the Living Wage linguistically conceives the young unemployed as less than alive due to their conceptually depreciated labour power.

One Million was imbued with the ambivalences surrounding young unemployed bodies embedded in this landscape of hypervisible unemployment, inferred unproductivity/latent productivity, and dehumanising labour practices. The piece highlighted the possible intervention this 
kind of arts practice offers in making visible alternative representations of young people and fostering important sensibilities of collectivity among this group of people. Concurrently, however, One Million inherently valorised active labour, resulting in notions of productivity remaining unchallenged. A further exploration of this valourisation of labour in participatory performance identifies broader tensions at play regarding production in such arts projects. Finally, given the current context of exploitative internships, which are increasingly prolific in the creative and cultural industries, the reparations for participants involved in One Million also merit investigation as both a consideration of the exploitation of unemployed bodies and a means of addressing value exchange in participatory performance. My analysis therefore considers how One Million enables participants to perform acts of gestural defiance, while also potentially modelling the precaritisation of labour which permeates the creative industries.
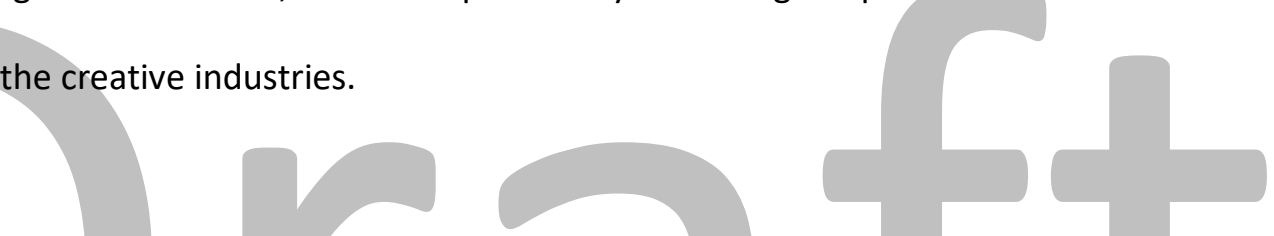

[INSERT Figure 1 captioned: Figure 1. One Million, Tangled Feet, Greenwich International Festival (2013).

Photograph courtesy of Nathan Curry.]
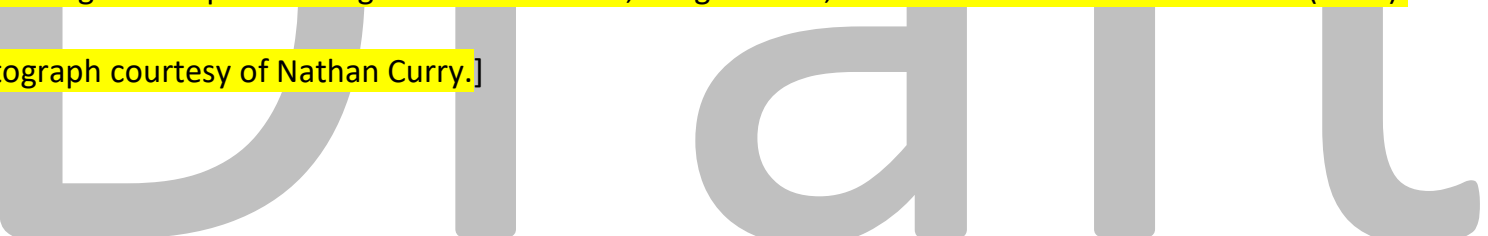

One Million demonstrated participants' dynamism as creative agents but also as potential employees, highlighting their vitality as living labourers. The aesthetic of the production featured sparse steel scaffolds and functional metal frames, invoking a lost industrial past that continues to negatively effect the UK labour market. This served to emphasise the shift from Fordist to postFordist systems of labour: in this post-industrial context, One Million rematerialised labour as a physical action, as the overt physicality of navigating the set made the performance and witnessing of physical labour acutely visible. A recurring motif of ladders in the production attested to the struggle to gain employment. One sequence depicted the cast scrambling up the central scaffold, racing to the top but falling before they could reach it, others grasped at dangling ladders attached to bungee ropes which were agonisingly out of reach or unstable. One acrobat repeatedly clambered up a pole but always slipped before reaching the top. Either side of the central frame, the two 
staircases were overrun with performers, cyclically racing one another to the top only to be pulled down before they could reach the central column. All around, bodies fell from the structure. This repeated gestural act indicates the production's central message: young people are, desperately and creatively, trying to engage the labour market; it is the flawed frameworks they are bound to which are failing them. It is useful to turn here to Carrie Noland's concept of 'embodied gestures', which explores the gesture as providing access to a kind of agency that might challenge dominant conceptions,

Kinaesthetic experience, produced by acts of embodied gesturing, places pressure on the conditioning a body receives, encouraging variations in performance that account for larger innovations in cultural practice that cannot otherwise be explained. (Noland 2009, 2-3)

In One Million, the participants' bodies move in a resistant or even deviant manner to the ways those bodies move as constructed within hegemonic welfare discourse. As a participatory piece One Million provided an opportunity for participants to reorient their bodies in relation to labour and to unsettle discourses of inactivity and unproductivity which define the bodily behaviours of the young unemployed. The kind of agency this might produce is twofold, in that these gestural repertoires advocate for unemployed lives as productive, in opposition to welfare discourses that construct those bodies as un- or not-yet productive. Concurrently, however, the performance also offered an overt embodiment of the labour processes at play in a neoliberal economy where value and agency is entwined with the productivity of the body.

When applied to the unemployed participant, this creation and contribution, this productivity, has the potential to become subversive. Rebecca Schneider argues that, if labour power is understood as a commodity, it too, like any other commodity, can be perceived as 'congealed or dead when not productively employed in generating capital for the capitalists' (Schneider 2012, 156). Drawing on Karl Marx, Schneider posits 'congealed or dead' labour is that which is not immediately in use and is framed as parasitic, dependent on living labour (the vital source of 
corporeal action which ensures the continued circulation and value of capital). Schneider goes on to consider the implications of this in/active categorisation of living and dead for the performer when acting on stage. I alluded earlier to the necropolitical construction of the young as unworthy of the living wage due to their perceived inactivity. Following Schneider, it becomes possible to explore and understand that such a status of congealment or death might also be attributed to these 'inactive' young unemployed bodies. In undertaking such a productive performance, then, I argue that such bodies, in creating ambiguity, undermine the central nexus of relationships between labour, value and the generation of capital that underpins the necro-political domain of a neoliberal economy.

The built scaffolds required participants to demonstrate their vitality by climbing and sliding their way across the performance space, which was itself mobile and dynamic. Artistic Director of Tangled Feet, Nathan Curry, commented on the power of the performance to contest public perceptions of young people as lethargic, disengaged and apathetic,

When you see someone perform you see their potential [...] It's not only about witnessing them full stop, but witnessing their potential, they are creative and vibrant and exciting opportunities. (Curry 2015)

[INSERT Figure 2 captioned: Figure 2. 'Climbing the Career Ladder', One Million, Tangled Feet, Greenwich International Festival (2013). Photograph courtesy of Nathan Curry.]

Seeing these bodies, so often defined by their inactivity, performing that very labour power undermined their allocation as inactive. As Judith Butler notes, in her call to reconfigure discourses of vulnerability as practices of resistance,

There is a plural and performative bodily resistance at work that shows bodies being acted upon by economic and social policies that are decimating livelihoods. But these 
bodies, in demonstrating this precarity, are also resisting those very powers. (2015,

n.p)

One Million, by depicting performers navigating this overbearing mobile structure, and at times falling from the scaffolding, overtly performed the precarity of the bodies in public space. Thus the production performed the oppression and resistance of the young, as participants concurrently underscored the labour policies which are 'decimating livelihoods' but also, in their constant return to and attempt to scale the scaffold, demonstrated their own persistence in this context.

Alongside the challenge to dominant representations of young unemployed people as unskilled and lazy, the production offered a space for collective representation and cultivated a sense of community. One Million provided a space for young bodies to gather and to demonstrate, as Curry noted, It is an invisible thing and [the production is] going, 'Here it is have a look.' [...] It gets to the stage where you're one of so many but it's so many, it's a million, it's not as if it's a hundred and you can go and find them [...] where those places are for them to meet and be. (Curry 2015)

One Million brought together and celebrated these isolated and dispersed bodies, creating a critical mass which, though present in the statistics, is absent from public space and consciousness in a material sense. The communal collectivity created by the performance extended beyond the cast, as the immersive aspects of the performance enveloped the audience in the action. This invitation to be part of a collective experience was amplified by the provoking climax of the piece, where Anaxagorou directly addressed the audience,

In times of austerity we must walk each other through, join lives, solder our hearts in solidarity 
look around you, everything is here,

alive, this is all we need,

a mighty stand expressed in numbers,

so go ahead and unite

to take back what has always been yours.

When I saw the performance, this scene was accompanied by shouts from a visibly stirred audience and a feverish soundscape created by the band, as the cast encircled the audience, glo-sticks aloft, creating a moment of visible, dissenting community, a body of people taking a stand. More broadly, One Million required the perceiving bodies of the audience to invest their energy in participants' narratives as they actively negotiated the scaffolds and pursue the action. The performance provided a powerful political intervention by resisting the concerns relating to the gathering of young people in public, and opening up an agentic space that presented the productivity of young bodies, both for participants themselves and also for those who witnessed them.

While I have thus far argued for participation as a means to challenge hegemonic discourse, I also acknowledge the possibility that arts practice engaging with unemployed participants risk reinforcing what feminist scholar Kathi Weeks has called the 'reification and depoliticization' of work $(2011,140)$. The promotion of participation in arts projects that reproduce uncritical discourses of creative forms of productivity resonates with governmental support for active labour market policies which 'enforce [benefits] conditionality on active job search and participation in measures to improve employability' (OECD 2014, 9, my italics). In the UK these measures include controversial initiatives like The Work Programme, Universal Credit, and the aforementioned tough sanctioning process, which similarly emphasise the implicit value in activity. As Weeks notes, 'a spectre haunts 
the revolutionary imagination: the phantom of production. Everywhere it sustains an unbridled romanticism of productivity' $(2011,81)$. This tethering of imagination and productivity underpins participatory arts practices which prioritises the idea of active participation. Here, the performance apparatus of participatory arts projects potentially sate public desire to bear witness to the unemployed body in a state of labour.

The unemployed body engaged in acts of unpaid labour is a regular and required feature of a participatory theatre project. Here I turn to Nicholas Ridout's $(2013,106)$ assertion that this kind of volunteered performance is 'not-not work'. Thus a particular consideration of engaging the unemployed in such activity refocuses the difficult ethical terrain in participatory arts projects: what does it mean to be complicit with the privileging of active labour? As a performance, One Million chimes with Claire Bishop's argument that the participation of marginalised groups in art projects often 'assumes that the poor can only engage physically, while the middle classes have the leisure to think and critically reflect. [This] reinstates the prejudice by which working class activity is restricted to manual labour' $(2012,38)$. As Bishop identifies, when undertaking participatory work with groups such as the unemployed, there is a risk of reinforcing the commodification and activation of poor bodies in the service economy. If we are to remain alert to the potentially exploitative nature of participation it is useful to reflect on forms of value exchange that operate in participatory performance.

In producing One Million, Tangled Feet constructed a complex mixed economy of labour. First, there were the 80 young unemployed participants, who were as Curry stated, '[p]aid a very small amount of money [...] It wasn't minimum wage, it was just about going "you're here, we witness that"' (2015). These participants were joined by ten professional performers and a further eight young people, who had been unemployed, to undertake roles on the production team. These contracted workers, despite being paid professional rates at this time, were (in common with freelance agents in the creative economy) negotiating their own positions of precarity and underemployment. So, the project operated as an employer but also a trainer, with both financial 
and experiential modes of remuneration being enacted depending on labourers' specific circumstances.

Following Ridout, I argue that placing those professional and amateur bodies in the same public space problematises the distribution of labour in contemporary society, both in the performance's content and its very form. As Ridout comments,

These are moments when politics might break out, not so much because of an absence of work or labour [...] but rather because the terms upon which the theatre is made [...] unsettle our capacity to distinguish between work and nonwork, poesis and praxis, the professional and the amateur. $(2013,16)$

This blurring of distinctions between paid labour and participation was actively sought through the casting of the 'professional' performers who were all in the 16 to 24 age bracket of youth unemployment. They were purposefully not visibly distinguished from the participant performers. As Curry recounts,

You don't know where the main cast ends and the participants start. So you might see someone doing something amazingly skilful on top of a bit of scaffolding and you might think it's a young unemployed person or it might be a professional gymnast. (Curry 2015)

The collective performance of these bodies undermines the objective exclusion of people from labour markets and any assumptions audiences might make as to which bodies were productive and which unproductive. The employed are indistinguishable from 'passionate amateurs': on the one hand demonstrating their capability to enact labour and so testify to their worth within the workforce, yet on the other producing value outside of the realm of financial transactions. While there is a need to further understand the critical potential of participation valorising productivity, I 
argue that One Million sought to reimagine a different, more democratic, approach to labour. As David Harvey notes,

even if labor under the domination of capital is condemned for the most part to produce the conditions and instruments of its own domination [...], the transformative and creative capacities of the labourer always carry the potentiality [...] to fashion an alternative mode of production, exchange, and consumption. $(2000,117)$

It is here that we can see the resistant potential of the performance of the unemployed body presented as a critical mass and in tandem with the paid labourer. Such projects with the unemployed are uniquely positioned to demonstrate 'the creative capacities of the [non] labourer' and so present different modes of 'production, exchange, and consumption'.

\section{Assessment, Categorisation, and Vulnerability}
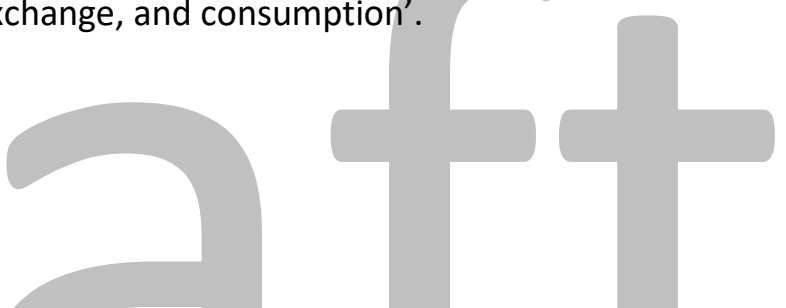

MindFULL provides a useful counterpoint to One Million, in the divergent manner it navigates the construction of unemployed bodies in order to similarly challenge dominant rhetoric in political and media discourse. While One Million presented a heightened physicalised performance of labour in which gestural resistance could be performed, MindFULL removed participants' bodies from the creative product in order to challenge the voyeurism that accompanies Employment Support Allowance (ESA) claimants. ESA is available to those citizens who are unemployed due to illness or disability, and as such this project also offers a more explicit investigation of participatory performance and necropolitics given the acute mortality, which I will outline below, ascribed to ESA claimants by current welfare policies in the UK. This second case study therefore builds on the analysis of participation I have outlined above and develops these arguments to further demonstrate how participatory performance might navigate the necropolitical construction of non-working sick bodies. 
In tandem with the stricter sanctioning process, and subsequent acute precaritisation of unemployed people, I outlined in my introduction in 2012 the government stopped releasing figures outlining the number of claimants who had died whilst receiving Employment Support Allowance. A return to Schneider's investigation of precarity and performance, argues for an extension of Butler's notion of precarity, proposing, 'persons with precarious deaths - persons who may not appear to live or to die, nor appear to count if dead. [...] Such beings cannot exist. But do' (2012: 151). Having previously denied the existence of such data, again refusing to count these bodies, in August 2015 government finally released figures pertaining to these deaths under a Freedom of Information application (DWP, 2015b). It revealed that between December 2011 and February 2014 2,380 people had died within a year of being declared 'fit for work'. Over the same period a further 7,200 people died within a year of being allocated to the Work Related Activity Group, a categorisation that require claimants to attend meetings and partake in Work Programme activities, leaving their claim susceptible to sanctions. ${ }^{5}$ As Frances Ryan points out, '[d]eath has become a part of Britain's benefits system. That is not hyperbole but the reality that the stress caused by austerity has led us to' (2015). It is painfully apparent that the struggle for correct corporeal categorisation of the unemployed emerges as indicative of the necropolitical strategies at play in employment policy.

MindFULL, provides an opportunity to further examine the politics of classification of the non-labouring body and consider how participatory arts practice might function in challenging, or nuancing, such corporeal classifications. State scrutiny of unemployed bodies, which is constant, is particularly acute when claimants are in receipt of ESA. Further, while the official classification of bodies as 'fit for work' is undertaken by the State, there is a heightened awareness of - and salacious interest in - ESA claimants in the media. Two headlines in the tabloid newspaper The Mirror newspaper around the time But I'm Here for Mental Health was made are indicative of the prevalent media discourse: 'Watch Benefit Cheat Who Claimed He was Unable to Walk RUNNING on Football Pitch' (Shammas 2015); 'Benefit Cheat Jailed After Being Caught on Camera DANCING in rock band' (Thornton 2015). The repeated desire is for the public to bear witness to these bodies in 
deceitful states of action, which the headlines capitalise to further emphasise. As Rosmarie GarlandThompson identifies 'staring can also be a social act that stigmatizes by designating people whose bodies are behaviours cannot be readily absorbed into the visual status quo' $(2009,44)$. How then can the bodily practice of participatory performance intervene in the scrutinised and stigmatised corporeal framing of disabled citizens?

But I'm Here for Mental Health, the film created by MindFULL participants, addresses the assessment process that defines people as un/fit for work. This evaluation begins with The Capability for Work Questionnaire (CWQ), which claimants must complete in order to apply and qualify for the benefit. As well as a section for broad descriptions of their illness and a section on mental health and cognitive ability, the questionnaire includes the following:

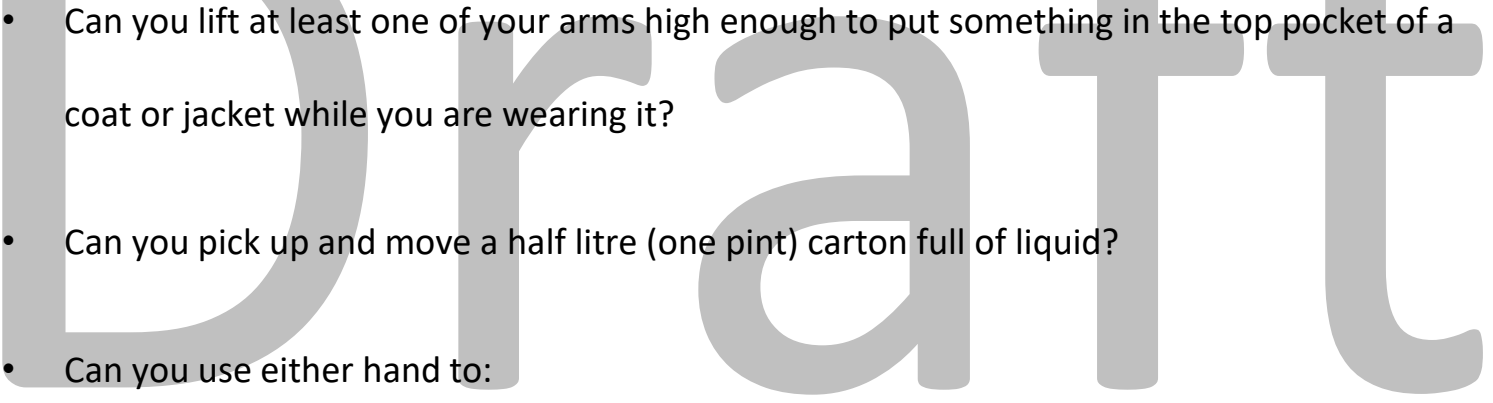

- Press a button, such as a telephone keypad

- Turn the pages of a book

- Pick up a $f 1$ coin

- Use a pen or pencil

- Use a suitable keyboard or mouse? (DWP 2015, 8-9)

Responses to the questionnaire are scored in accordance with a points system, which is combined with claimants' point score at their face-to-face assessment. Assessors do not take into account claimants' medical records or seek information from their GPs. 
A scene in But I'm Here for Mental Health depicts the character of Alan undergoing his faceto-face assessment. Alan is put through a physical assessment in which he mirrors the movements of his assessor: holding his arms out, turning his hands over, touching his toes. He does not speak in the scene but is instructed by the voice of his assessor. In an accompanying voiceover Alan explains his work history and health condition to viewers. This creates a clashing of discourse spaces, one in which the character's narrative can be heard and one in which he can only respond on a purely bodily level. The juxtaposition in this scene is pointedly located. For example, Alan explains,

VOICE OVER: I was unfairly dismissed

ASSESSOR: Can you touch your toes?

The film evidences the rendering mute of this community as, within the discourse space of the assessment, a voyeuristic view of the body is all that is valued. This resonates with the singular voice narrating One Million: in both instances participants are voiceless. However in the Helix Arts project there are no acts of gestural defiance, indeed the completely compliant body alongside the accompanying narration reveals the character's acute anguish. The questions in the Capability for Work Questionnaire and the scene depicting the assessment construct the body and its work in the form of mechanised labour, via a series of inorganic, routinised, decontextualised processes, rather than as the dynamic and bodily enactment of productive living labour. The damaging objectification of bodies in unemployment discourses dehumanises respondents and supports a practice of 'looking without recognising, a separate stare that refuses to move towards one's fellow human' (GarlandThompson 2009, 186). The questionnaire is underpinned by a policy rhetoric and mechanised bureaucracy that puts human experience at such a distance that claimant populations are constructed as, in Butler's terms, less than living. In giving voice to the inner narrative of the characters in the film, MindFULL enables a more complex understanding of claimants to emerge than one entirely anchored in the body. 
In representing this community of claimants the project was at risk of reproducing the voyeuristic schematics of the welfare system it sought to critique. However, due to the pervasive fear of financial sanctioning of participants, MindFULL retained the anonymity of those involved by removing their actual bodies from the film. In participatory performance, the possibility of substituting bodies allows for a break from the representational labour constantly being undertaken by the unemployed and counters the intense focus of claimants' physical encounters in ESA discourse. This is in direct contrast to One Million where resistance lay in the presentation of the participants in the act of representational labour sought to challenge dominant perceptions of the young unemployed as inactive. While One Million raised concerns surrounding the valorisation of labour, MindFULL utilised a different mode of creative labour in the gathering and presentation of participants' personal stories. As such MindFULL elicits concerns around the ethics of representing particular subject positions and the co-optation of community created stories by arts companies. These concerns were navigated by Helix through collaborating with participants to design a brief for film-makers which outlined their project and required interested parties to apply with proposals. Helix had a number of applications that proposed different strategies to navigate the displacement of bodies including the use of animation, clay models, and actors. Participants were involved in selecting the proposal they felt utilised the best approach and thus were constantly in control of creative decisions taken regarding the retelling of their stories.

In this way, the project allowed bodies to be both represented and anonymised. Further, removing bodies from view encourages reflection on how artists represent the materiality of unemployment. While in One Million participants' bodily presence served to powerfully render them collectively visible in a context that had reduced their materiality to mere statistics, in MindFULL the gesture of absence serves to undermine the focus on bodies that has been applied to ESA claimants. Poignantly, the absence of participants' bodies haunts the film, signifying their experience of relentless corporeal evaluation. This de-privileging of participants' bodies in But I'm Here for Mental Health underscores the importance of the narratives which emerge in the film, and avoids constantly 
returning to and reinforcing the negative perceptions of bodies to which those narratives are attached. ${ }^{6}$ Thus corporeal absence from the film underscores the need to prioritise the narrative life of claimants, rather than the skewed presentation of the material body in ESA policy and provision, in order to reconstitute the subject as living.

Importantly, the film acknowledges the support needs of mental health claimants as well as those with physical disabilities in a context where $43 \%$ of claimants are accessing the benefit due to 'mental or behavioural problems' (Beatty and Fothergill 2015, 168). Such claimants are often erased, or worse reproached, by body-focused media rhetoric surrounding ESA due to a desire for the sickness to be visibly embodied and evidenced, and condemnation if this visibility is not consistently and coherently performed. The deeply embedded relationship between capital and the categorisation of the unemployed body is characteristic of a capitalist economy, as David Harvey notes, 'sickness is defined under capitalism broadly as inability to work' $(2000,106)$. The film demonstrates that understandings of sickness have become increasingly contested in relation to assessment as fit or unfit to work and argues for a broader understanding of sickness than is currently accepted by the State. MindFULL allowed participants to communicate the less visible effects of their illnesses and also provides the narrative scope - lacking from popular, soundbitedriven rhetoric - to display the differing experiences of physicality they each encounter. This aligns with Garland-Thompson's call for a 'visual politics of deliberatively structured self-disclosure' (2009, 193). In providing more nuanced understandings of 'the healthy body', the film challenges the State regulation of bodily 'fitness' in relation to labour.

\section{Conclusion}

I have argued that participatory performance has the potential to challenge biopolitical and necropolitical constructions arising from governance systems and to support individuals in challenging dominant constructions of unemployment through a politicisation of their bodies. In Spaces of Hope Harvey draws upon Donna Haraway to anchor his reflection on the resurgence of 
theoretical interest in the body, stating that 'it is crystal clear to me that the body is an accumulation strategy in the deepest sense' (Haraway in Harvey 2000, 97). Harvey argues that the openness and malleability of the body enables it to be read as a political agent. I propose that participatory theatre practice can powerfully tether the experience of the unemployed to this notion of the accumulating and strategic body. In One Million the ambiguity of apparently unproductive bodies being witnessed as productive resulted in an accumulation of status by those previously deemed disposable. There was an activation of bodies, both physically and politically, leading to a publically enacted activism of bodies. Similarly, MindFULL reoriented a societal voyeurism around disability claimants' bodies, which are also relentlessly objectified by welfare policy, to instead highlight and debunk our own looking. This strategy allowed narratives to emerge that were not located in the visible physicality of the sick body. My consideration of what is at stake when these marginal bodies perform labour articulates how the different approaches to participatory performance's embodied practice might provide aesthetic modes of resistance. Although participatory performance risks unquestioningly validating the value of labour, a self-reflexive approach to performing labour is uniquely positioned to critique it through the powerful aesthetic and symbolic tools it accesses. At a point when social welfare is being dismantled by the political ideology of austerity, participatory performance can function to support the agency of participants in challenging policy and re-establishing the status of subjecthood to their precarious bodies.

\section{Acknowledgement}

I would like to thank Jenny Hughes, Jen Harvie, and Caoimhe McAvinchey for their thoughtful guidance, energising discussion, and generous support in the writing of this article.

\section{References}

Beatty, Christina and Fothergill, Stephen. 2015. 'Disability Benefits in an Age of Austerity.' Social Policy \& Administration, Special Issue: New Perspectives on Health, Disability, Welfare and the Labour Market 49 (2): 161-181. 
Butler, Judith. 2004. Precarious Life: The Powers of Mourning and Violence. London: Verso.

Butler, Judith. 2012. 'Precarity Talk: A Virtual Roundtable with Lauren Berlant, Judith Butler, Bojana Cvejic, Isabell Lorey, Jasbir Puar and Ana Vujanovic.' TDR: The Drama Review 56 (4): 163-177.

Butler, Judith. 5 February 2015. 'Vulnerability and Resistance Revisited.' Lecture at Trinity College Dublin. Available at: $<$ https://soundcloud.com/joke-dufourmont/judith-butler-vulnerability-andresistance-revisited $>$ [Accessed September 24, 2015]

Curry, Nathan. 2015. Unpublished interview with the author. February 8 (London).

Dathon, Michael. 2015. 'Workers under 25 "don't deserve living wage because they're not as productive" says Tory minister.' Independent, October 6.

http://www.independent.co.uk/news/uk/politics/workers-under-25-dont-deserve-living-wagebecause-theyre-not-as-productive-says-tory-minister-a6683851.html> [Accessed July 25, 2016]

Department for Work and Pensions (2015), Capability for Work Questionnaire Available from $<$ https://www.gov.uk/government/publications/capability-for-work-questionnaire $>$ [Accessed June $12,2014]$

Department for Work and Pensions. 2015b. Mortality Statistics: Out of Work Working Age Benefit Claimants, August 2015. Available from <https://www.gov.uk/government/statistics/mortalitystatistics-esa-ib-and-sda-claimants $>$ [Accessed September 15, 2015]

Foucault, Michel. 1978. The History of Sexuality: An Introduction. London: Penguin.

Garland-Thompson, Rosemary. 2009. Staring, How We Look. Oxford: Oxford University Press.

Haraway, Donna. 1995. 'Nature, Politics and Possibilities: A Debate and Discussion with David Harvey and Donna Haraway.' Society and Space 13 (October): 507-527.

Harvey, David. 2000. Spaces of Hope. Edinburgh: Edinburgh University Press.

Lewis, P., et al (2015). Reading the Riots: Investigating England's Summer of Disorder, London School of Economics and the Guardian. Available at:

<http://eprints.Ise.ac.uk/46297/1/Reading\%20the\%20riots\%28published\%29.pdf > (accessed 15 March 2015).

Membe, Achille. 2003. 'Necropolitics.' Trans. by Libby Meintjes. Public Culture 15 (1): 11-40.

Noland, Carrie. 2009. Agency and Embodiment: Performing Gestures/Producing Culture. Cambridge: Harvard University Press.

OECD (Organisation for Economic Co-operation and Development). 2014. Connecting People with Jobs: Activation Policies in the United Kingdom. OECD Publishing. 
Office of National Statistics. 2011. 'Labour Market Statistics, November 2011'. Available from <http://webarchive.nationalarchives.gov.uk/20160105160709/http://www.ons.gov.uk/ons/rel/Ims/l abour-market-statistics/november-2011/statistical-bulletin.html> [Accessed May 14, 2016]

Office of National Statistics. 2013. 'Labour Market Statistics, November 2013.' Available from <http://webarchive.nationalarchives.gov.uk/20160105160709/http://www.ons.gov.uk/ons/rel/Ims/l abour-market-statistics/november-2013/statistical-bulletin.html> [Accessed May 14, 2016]

Office of National Statistics. 2016. 'UK Labour Market: June 2016.' Available from <https://www.ons.gov.uk/employmentandlabourmarket/peopleinwork/employmentandemployeety pes/bulletins/uklabourmarket/june2016> [Accessed June 20, 2016]

Ridout, Nicholas. 2013. Passionate Amatuers: Theatre, Communism and Love. Ann Arbor, MI: University of Michigan Press.

Ryan, Francis. 2015. 'Death Has Become a Part of Britain's Benefits System.' Guardian, August 27. Available from <http://www.theguardian.com/commentisfree/2015/aug/27/death-britains-benefitssystem-fit-for-work-safety-net> [Accessed August 28, 2015]

Schneider, Rebecca. 2012. 'It Seems As If...I am Dead: Zombie Capitalism and Theatrical Labour.' TDR: The Drama Review 56 (4): 150-162.

Shammas, John. 'Watch Benefits Cheat Who Claimed He Was Unable to Walk RUNNING On Football Pitch', Mirror, 13 February 2015< http://www.mirror.co.uk/news/uk-news/watch-benefits-cheatwho-claimed-5158667> [accessed 15 March 2015].

Thornton, Lucy. 'Benefit Cheat Jailed After Being Caught on Camera DANCING in rock band'. Mirror, 18 July 2014 <http://www.mirror.co.uk/news/uk-news/disability-benefit-cheat-jailed-after3880251> [accessed 15 March 2015].

Tinson, Adam. 2015. The Rise of Sanctioning in Great Britain. New Policy Institute. Available from <http://npi.org.uk/files/1314/3444/4908/Sanction report 1606.pdf>

Trussel Trust. 2016. The UK Foodbank Network. See: <https://www.trusselltrust.org/>

Sutton Trust. 2014. Internship or Indenture. Available from <http://www.suttontrust.com/wpcontent/uploads/2014/11/Unpaid-Internships.pdf> [Accessed September 9, 2015]

Helix Arts, Tyneside Mind, and Meerkat Films. 2013. But I'm Here for Mental Health. Available from <https://www.youtube.com/watch?v=tTaezvvQfOs> [Accessed February 1, 2014]

United Nations. 2006. 'Concluding Observations on the Sixth Periodic Report of the United Kingdom of Great Britain and Northern Ireland.' Available from < $\underline{\text { https://documents-dds- }}$ 
4, 2016]

Weeks, Kathi. 2011. The Problem with Work: Feminism, Marxism, Antiwork Politics and Postwar Imaginaries. New York and London: Duke University Press.

${ }^{1}$ The programme of austerity currently in place in the UK is a group of economic policies that aim to tackle the budget deficit through successive cuts to public spending and tax benefits, reduction in social security, redundancies across public services, and raises in taxes.

2 In 2013 the number of people sanctioned topped 2 million people, whereas between 2001 and 2009, on average the figure was 675,000. The average duration of a JSA sanction is eight weeks with an average loss of income of around $f 530$ in 2013-14 (Tinson 2015, 5).

${ }^{3}$ The work was performed again at Brighton Festival in May 2014 with a different group of unemployed young people.

${ }^{4}$ In this context youth unemployment refers to 16-24 year olds actively seeking work who are not in employment, education, or training.

${ }^{5}$ Between November 2012 and September 2013, nearly 20,000 ESA claimants were sanctioned, three-quarters for not participating in work-related activity (Beatty and Fothergill 2015, 177).

${ }^{6}$ Further, this allowed for the film to be shown at public events and released online. See: https://www.youtube.com/watch?v=tTaezvvQfOs [Accessed March 12, 2014]. 